\title{
Data-driven insights into correlation among geophysical setting, topography and seafloor sediments in the Ross Sea, Antarctic
}

\author{
Insights baseados em dados sobre a correlação entre configuração geofísica, topografia e \\ sedimentos do fundo do mar no Mar de Ross, Antártica
}

\author{
Polina Lemenkove \\ Analytical Center. Moscow, Russia \\ pauline.lemenkova@gmail.com
}

\begin{abstract}
Detailed mapping based on the high-resolution grids, such as GEBCO, ETOPO1, GlobSed, EGM2008 is crucial for various domains of Earth sciences: geophysics, glaciology, Quaternary, sedimentology, geology, environmental science, geomorphology, etc. The study presented a GMTbased scripting technique of the cartographic data processing aimed at the comparative analysis of the bathymetry, sediment thickness, geologic objects and geophysical settings in the study area based on various datasets. The study area is located in the Ross Sea, Antarctic. The highest values of the sediment thickness over 7,500 $\mathrm{m}$ are dominating in the southwest segment of the Ross Sea closer to the Victoria Land, followed by the region over the Ross Ice Shelf with values between 5,500 to $7,000 \mathrm{~m}\left(170^{\circ}-175^{\circ} \mathrm{W}\right)$. The increased sediment thickness $(2,500$ to $3,000 \mathrm{~m})$ was also mapped seen in the region NE off the Sulzberger Bay $\left(70-75^{\circ} \mathrm{S}\right.$ to $\left.140-155^{\circ} \mathrm{W}\right)$, caused by the closeness of the Marie Bird Land ice coasts. A remarkable correlation between the gravity and the topography of the sea-land border in the Marie Bird Land area is well reflected in the coastal line and a set of the higher values in the free-air gravity. On the contrary, negative values ( -60 to -80 $\mathrm{mGal}$ ) are notable along the submarine troughs stretching parallel in the western part of the basin: e.g. the trough stretching in NW-SE direction in the $170^{\circ} \mathrm{W}-175^{\circ} \mathrm{E}, 65^{\circ} \mathrm{S}-68^{\circ} \mathrm{S}$, between the $167^{\circ} \mathrm{W}-$ $175^{\circ} \mathrm{W}, 70^{\circ} \mathrm{S}-72^{\circ} \mathrm{S}$. Such correlations are clearly visible on the map, indicating geological lineaments and bathymetric depressions correlating with gravity grids. The paper contributes to the regional studies of the Ross Sea, the Antarctic and Polar region, and development of the technical cartographic methodologies by presenting an application of the GMT for thematic mapping.
\end{abstract}

Keywords: Ross Sea, Antarctic, Southern Ocean, Cartography, Geophysics, Bathymetry, GMT.

\section{Resumo}

O mapeamento detalhado com base em grades de alta resolução, como GEBCO, ETOPO1, GlobSed, EGM-2008 é fundamental para vários campos das ciências da terra: geofísica, glaciologia, quaternário, sedimentologia, geologia, ciências ambientais, geomorfologia, etc. O estudo apresenta métodos de processamento de dados de mapas com script baseado em GMT visando a análise comparativa de batimetria, espessura de sedimentos, características geológicas e condições geofísicas na área de estudo com base em vários conjuntos de dados. A Área de Estudo está localizada no Mar de Ross, na Antártica. Os valores mais altos de espessura de sedimento de mais de $7.500 \mathrm{~m}$ prevalecem no sudoeste do Mar de Ross próximo a Victoria Land, seguido pela área acima da plataforma de gelo de Ross em valores entre 5.500 e $7.000 \mathrm{~m}\left(170^{\circ}-175^{\circ} \mathrm{W}\right)$. O aumento da espessura do sedimento (de 2.500 a $3.000 \mathrm{~m}$ ) também foi mapeado na área nordeste da Baía Sulzberger (de 70-75 ${ }^{\circ} \mathrm{S}$ a $140-155^{\circ} \mathrm{W}$ ), devido à proximidade das costas de gelo da Terra Marie Bird. A notável correlação entre a gravidade e a topografia da fronteira marítima perto da Terra Marie Bird é bem refletida na linha costeira e em muitos dos maiores valores de gravidade ao ar livre. Em contraste, os valores negativos (-60 a -80 mGal) são perceptíveis ao longo das muralhas 
submarinas que se estendem paralelamente na parte oeste da bacia: por exemplo, uma trincheira que se estende na direção noroeste-sudeste a $170^{\circ} \mathrm{W}-175^{\circ} \mathrm{E}, 65^{\circ} \mathrm{S}-68^{\circ} \mathrm{S}$, entre $167^{\circ} \mathrm{W}-175^{\circ} \mathrm{W}, 70$ ${ }^{\circ} \mathrm{S}-72^{\circ} \mathrm{S}$ Essas correlações são claramente visíveis no mapa, indicando lineamentos geológicos e depressões batimétricas correlacionadas com grades gravimétricas. $\mathrm{O}$ documento contribui para estudos regionais do Mar de Ross, Antártica e região polar, bem como para o desenvolvimento de metodologias técnicas de mapeamento, introduzindo a aplicação GMT para mapeamento temático.

Palavras-chave: Mar de Ross, Antártico, Oceano Antártico, Cartografia, Geofísica, Batimetria, GMT.

\section{INTRODUCTION}

The study presents an analysis of the geophysical and topographic settings of the Ross Sea, a marginal Sea of the Antarctic located between the Victoria Land and Marie Byrd Land, within the Ross Embayment. As the global environmental change increases, the interest in the role of marginal seas of the Antarctic and the potential impact of ice fluctuation in climate change contribution is renewed. Despite the variety of research on Antarctica as a continent, there is relatively little research on the Ross Sea of the concept of sediments and relations between the geologic and bathymetric settings and sediment thickness on the seafloor. Moreover, although the focus of scientific research on Antarctic research has been increasing rapidly along with ongoing expeditions and collected data, the complex comparative analysis of the geophysical, geological and bathymetric settings of the Ross Sea basin still insufficient, thus creating needs in the creating of a series of the thematic maps of the Ross Sea. Determination of the importance of geological and glaciological conditions of the South Pole as well as submarine geomorphology of the Ross Sea is relevant to the analysis of the sediment distribution over the seafloor of its basin. At the same time, cartographic visualization of these parameters provides an opportunity to analyses impacts to variation in sediment thickness by identifying factors and directions of the sediment inflow with regards to the terrain relief and bathymetry.

In the framework of this research, the objectives were as follows: which depths of the seafloor are the most repetitive for the Ross Sea, and how can knowledge on geophysical setting be used to explain the correlation between the geomorphology and landforms of the various part of the sea. The unaccessible study area of the southernmost sea on Earth situated in harsh climatic conditions and big datasets available to undertake the study controlled these questions and enabled mapping by the Generic Mapping Tools (GMT). Visualising the structure of the seafloor bathymetry of the Antarctic area as the most remotely located region playing an essential role in the global climate cycle helps to improve our knowledge of the Earth, its functionality and intricate processes that take place in the oceans. Technical examples of the GMT functionality improves the cartographic methods and presents alternative ways for mapping rather than traditional GIS. 


\section{REGIONAL SETTINGS}

The Ross Sea is located on the border of the East-West Antarctic margin. The Ross Sea is one of two seas around Antarctica (together with the Weddell Sea) with a broad continental shelf (Figure 1). The geologic development of the Ross Sea basin, faults, grabens and crustal extension started during the rifting away of the Zealandia microcontinent from Antarctica in Gondwana during Cretaceous (LAWVER \& GAHAGAN, 1994). The faulting in the Victoria Land Basin, located westwards, took place in Paleogene and Neogene (DAVEY et al., 2006) and has been extending in a $170 \mathrm{~km}$ of ENE-WSW direction forming the Adare Basin. The most of the extension in the Adare Basin continued into the Northern Basin of the Ross Sea which was formed by a combination of crustal thinning and massive, narrowly focused intrusions (CANDE et al., 2006).

The study area has the following quadrant coordinates: $160^{\circ} \mathrm{E}$ to $140^{\circ} \mathrm{W} ; 81^{\circ} \mathrm{S}$ to $40^{\circ} \mathrm{S}$ (Figure 2). The western part of the Ross Sea is formed by the Transantarctic Mountains, a rift mountain range formed in the Cretaceous (BRANCOLINI et al., 1997; DAVEY et al., 2006) presenting the margin between the East Antarctic craton and the lithosphere of the Ross Sea. The Transantarctic Mountains approach the coast in this region with occasional tongues of glaciers reaching the sea. The range of the water depths in the shelf are at 200-1100 m, with varying three north-south-trending sedimentary basins: The Eastern basin, Central trough, and Victoria Land basin (COOPER et al., 1987). The crystalline basement surface on the shelf is presented by the Precambrian structures, in the area of Mary Byrd Land - by the Cenozoic structures (DECESARI, 2006). The geomorphology is complicated by marginal depressions, the largest of which are located in the Ross Sea basin, extending under the Ross Ice Shelf. The crystalline basement has elevations between local bathymetric depressions. It descends stepwise to the pre-continental troughs situated along the shelf edge of the Ross Sea. The basement encircles the submarine margin of Antarctica in the zone of the continental slope, where depths exceed 6,000 $\mathrm{m}$.

The geomorphology of the coasts is mountainous, with highly indented coastlines. The southern part of the sea is covered by the largest Ross Ice Shelf, extending north to approximately $72^{\circ} \mathrm{S}$ (PARISH et al., 2006). The Ross Sea is strongly influenced by sea ice, which covers large areas of its surface. Its open part is occupied by the drifting ice including icebergs, with a perimeter of tens and hundreds of kilometers. The sea is inhabited by the Ross seal, Weddell seal, whales, Antarctic petrels, Thalassoica antarctica, penguins, a variety of fishes and other Antarctic Polar fauna (AINLEY 1985; SAINO \& GUGLIELMO, 2000; EASTMAN, 2005; ARRIGO et al., 2002: EASTMAN \& BARRY, 2002). The seafloor bottom of the Ross Sea includes the OligoceneQuaternary terrigenous and siliceous iceberg deposits with a $413 \mathrm{~m}$ thickness (LITVIN, 1987). Late Oligocene and younger sedimentary rocks have also been drilled in the Victoria Land basin by 
Cooper et al., (1987). Lower Paleozoic marbles and gneisses were found beneath this layer. The continental slope of the Ross Sea has a terrace structure, with varying steepness and dissection. A hilly bathymetry characterises the outer shelf with depths ranging from 300 to $450 \mathrm{~m}$. The depressions associated with transverse troughs have the depths exceeding $500 \mathrm{~m}$.

Topographic map of the Antarctic

ETOPO1 Global Relief Model 1 arc min resolution grid

Polar stereographic conformal projection, scale 1:60,000,000

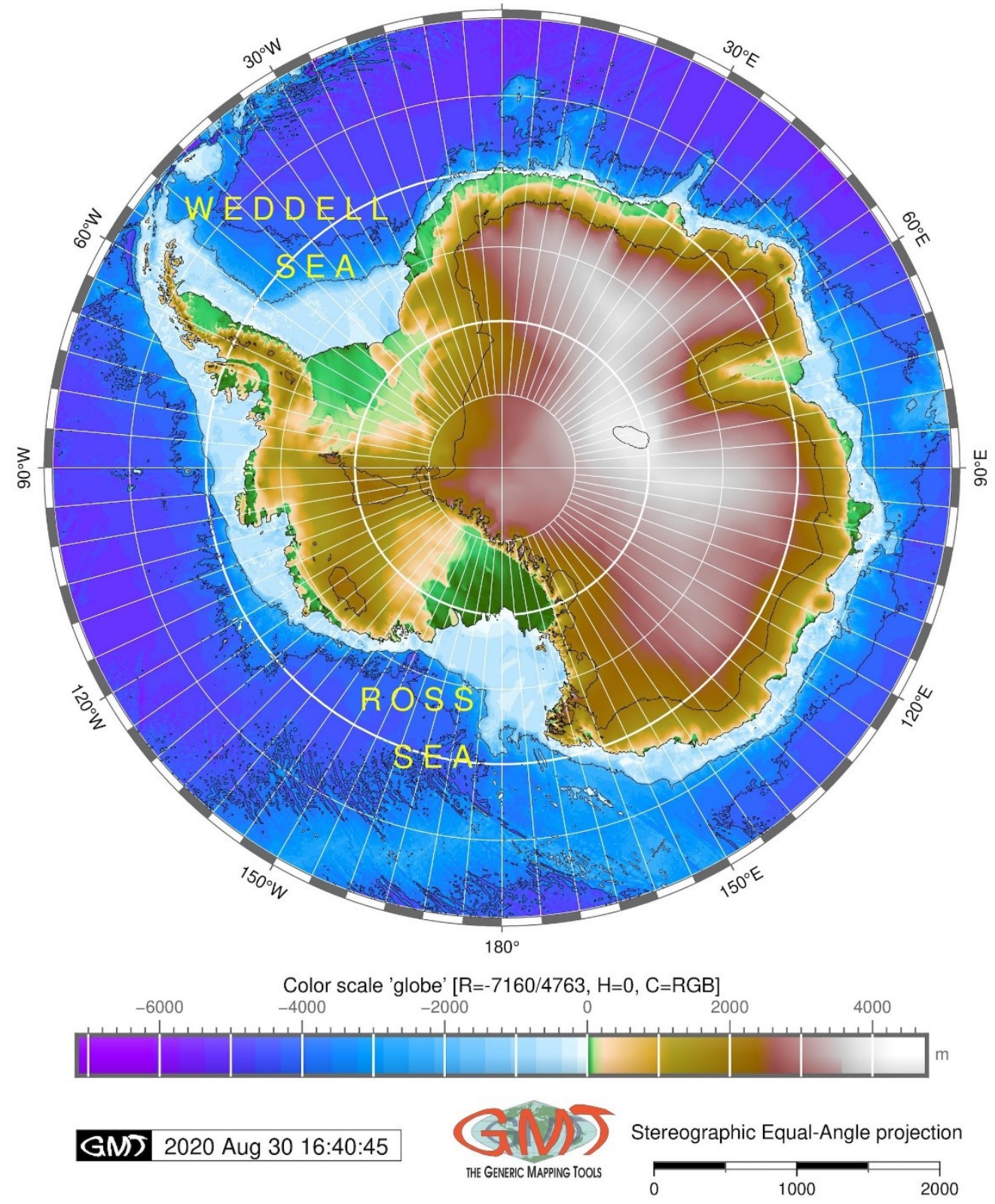

Figure 1 - Topography of the Antarctic with the spatial location of the Ross Sea and the Weddell Sea. Source: author.

The bathymetry of the Ross Sea varies geographically, which deserves a brief description. Its shelf area in southern and central parts is relatively shallow (dominating depths are less than 500 
$\mathrm{m})$. However, the dominating depths in its northern part are over 2,000 $\mathrm{m}$. In the western part of the Ross Sea, along the coast of Victoria Land, the coastline is heavily indented with an uneven irregular length. Overall, the Ross Sea bathymetry slopes northward due to the isostatic depression of the continent from the heavy mass of the polar ice cap (AINLEY, 2010).

This correlates with the findings of Jacobs \& Comiso (1989) who found that the ice cover over the shelf is persistently lower than above the deep ocean in its northern sector, averaging $86 \%$ during winter with little variability. Such a south-north variability is also caused by the warmer subsurface water entering the southern shelf region year-round, retarding ice growth and enhancing heat flux to the atmosphere. However, recent measurements in the Ross Sea (JACOBS et al., 2002) indicated changes in the climate and glacial settings: a decrease in shelf water and surface salinity, atmospheric and ocean warming (at depths ca. $300 \mathrm{~m}$ ) north of the shelf and thinning of southeast ice shelves. The complex interrelation between the geological and glacial and climatic processes in the Antarctic and methods of visualization has also been previously discussed by Kuhn et al., (2006) and Gauger et al., (2007). From the adjacent land areas, the Ross Sea basin has been filled by sediments brought by glaciers, currents and the wind, with gravel, sand and clay that thickens in a southern direction closer to the Ross Ice (Figure 4).

\section{MATERIALS AND METHODS}

Mapping oceanic seafloor geomorphology data from the bathymetric maps should be based on the high-resolution data to highlight isolines enabling to interpret steepness and gradient, which requires specific cartographic interpretation. Therefore, high-resolution GEBCO bathymetric and ETOPO1 topographic grids were taken to map figure 1 and figure 2.

Besides GEBCO, vector layers depicting coastal areas, Antarctic border shorelines included in the GMT were used for mapping based on the GSHHG (WESSEL \& SMITH, 1996). The regional map of the Antarctic (Figure 1) was done using the ETOPO1 1 Arc-Minute Global Relief Model grid developed initially by NOAA (AMANTE \& EAKINS, 2009). The local map of the Ross Sea (Figure 2) was based on the GEBCO grid (GEBCO, 2020). The boundaries of the tectonic plates (Figure 3) were derived from Bird (2003). The sediment thickness map (Figure 4) has been plotted using the high-resolution GlobSed map (STRAUME et al., 2019). The marine gravity model (Figure 5) was plotted based on the satellite-derived grid from the CryoSat-2 and Jason-1 (SANDWELL et al., 2014), and the geoid model (Figure 6) was based on the EGM-2008 grid (PAVLIS et al., 2012).

The datasets were sourced from the available repositories and imported into the Generic Mapping Tools (GMT), a scripting toolset developed by Paul Wessel and Walter Smith, (WESSEL 
\& SMITH, 1991). The additional processing of the grids has been done by GDAL (GDAL/OGR, 2020). The data were georeferenced, projected and processed using a standard cartographic workflow of GMT (LEMENKOVA, 2019b, 2019d) based on the scripting syntax of GMT (WESSEL \& SMITH, 1995). After the data were selected and collected, the research has been performed in GMT in several stages described below stepwise.

Bathymetric map of the Ross Sea region

GEBCO global terrain model, 15 arc sec resolution grid

Polar stereographic conformal projection. Central meridian $170^{\circ} \mathrm{W}$, standard parallel $60^{\circ} \mathrm{S}$

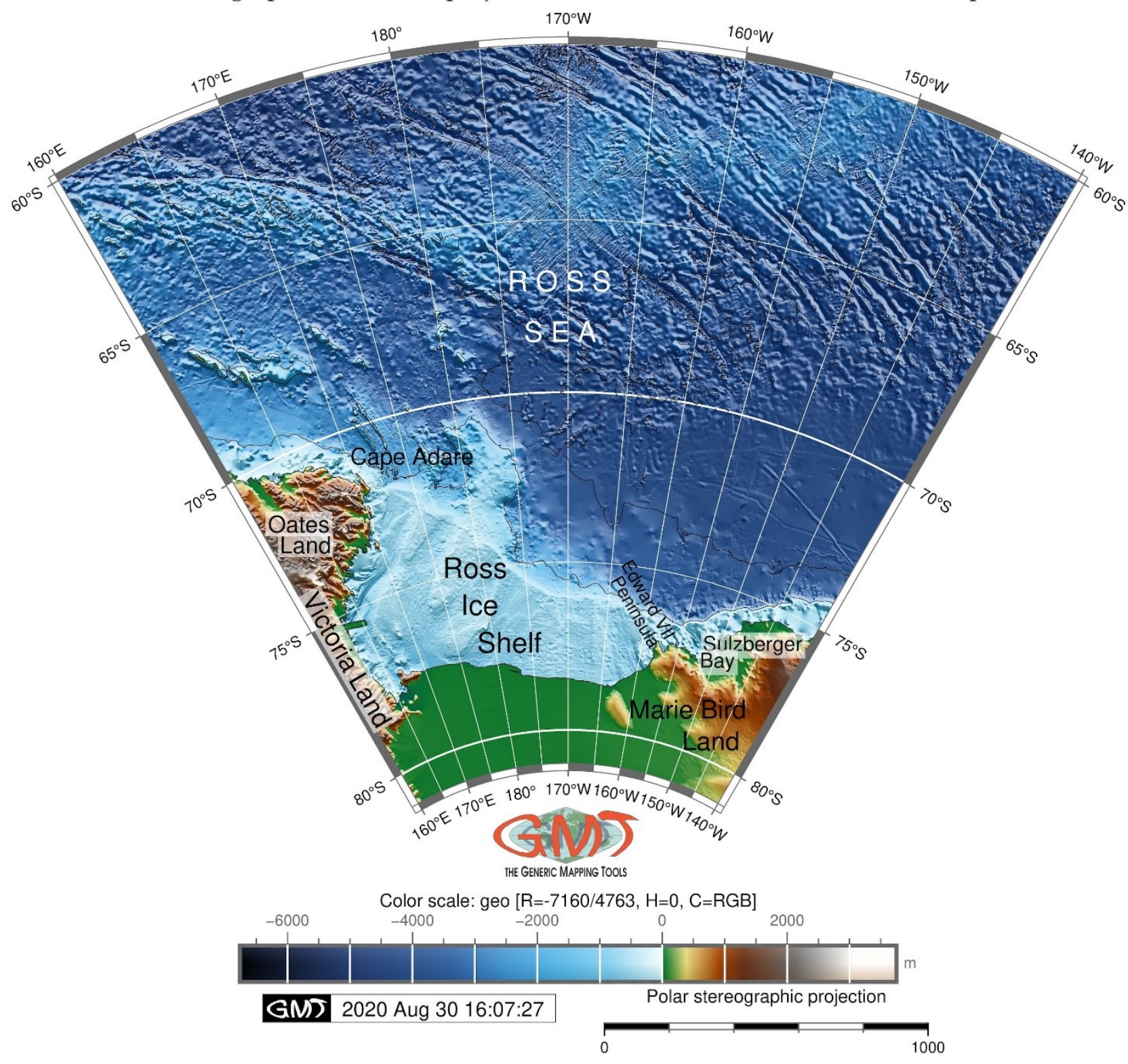

Figure 2 - Bathymetry of the Ross Sea. Source: author.

The first stage of the research involved the grid data projection by GMT. Several cartographic projections were used: Polar stereographic conformal (equal-angle) with the circular 
extent (Figure 1) covering Antarctica and a fan-shaped extent (Figure 2, 3 and 4) specifically for the region of the Ross Sea. The Lambert Azimuthal equal-area projection has been applied for mapping figure 5, and the Mercator projection was selected for figure 6.

Tectonic settings in the Ross Sea region

GEBCO global terrain model, 15 arc sec resolution grid

Polar stereographic conformal projection. Central meridian $170^{\circ} \mathrm{W}$, standard parallel $60^{\circ} \mathrm{S}$

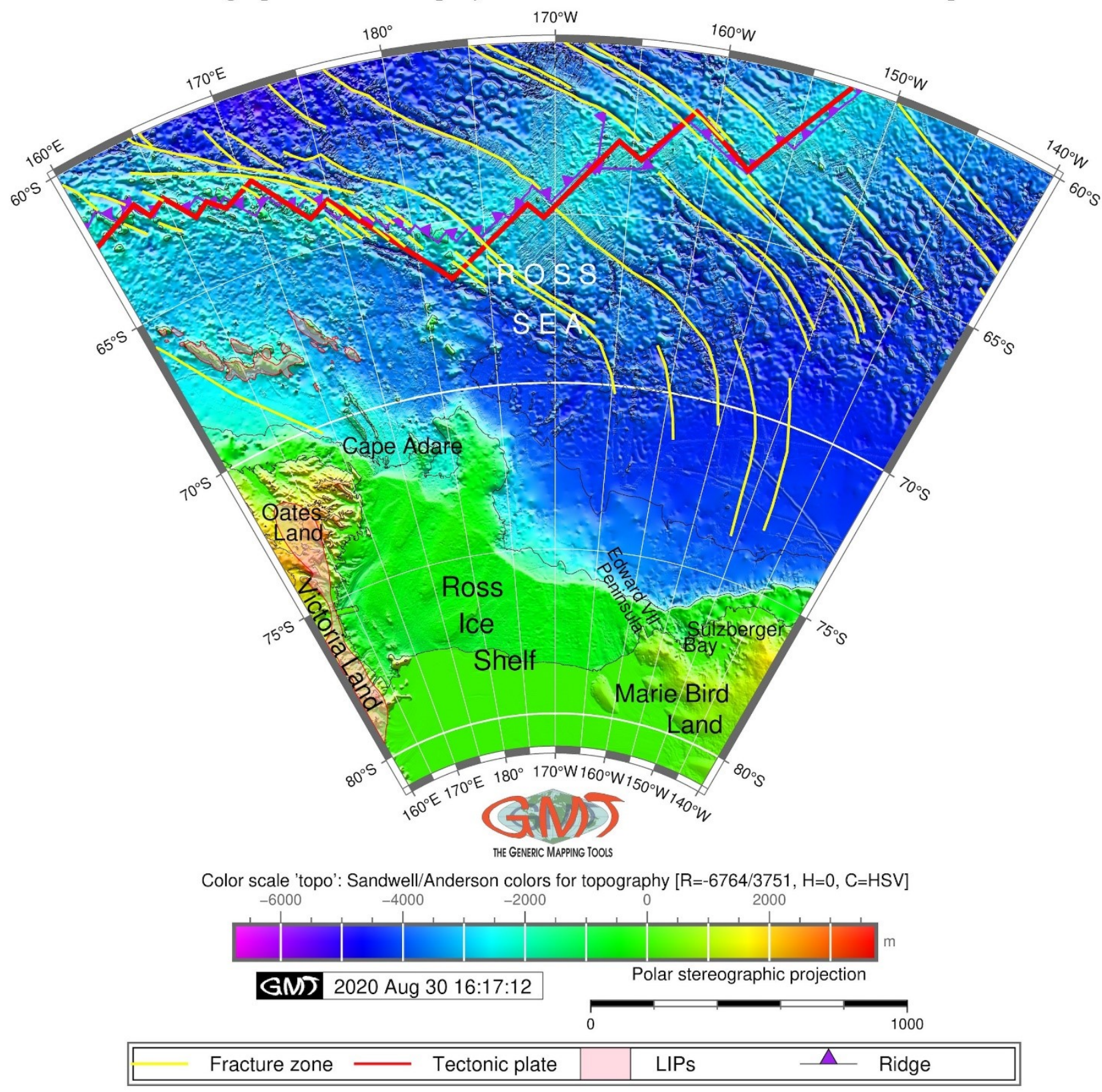

Figure 3 - Tectonics of the Ross Sea. Source: author.

The variety of the projections reflects better visualisation of the segments of the Earth with various distortions along the parallels and meridians (GODCHILD, 1992; LECHTHALER, 2009). Technical plotting of the maps was made using GMT module 'grdimage' with different flags for 
Lambert Azimuthal (-JA190/-70/5.5i), Polar stereographic conformal (-Js190/-90/5.5i/-60) and Mercator (-JM5.5i), respectively. The second stage of the research included plotting using GMT based scripting by a variety of modules for data processing and visualisation. The next requirement was to determine the study area by flag '- $R$ ' (in this case, -R160/220/-81/-60) that subsets the selected region from the global grids. This was applied for all the processed data: GEBCO, ETOPO1, EGM-2008, GlobSed. The isolines were plotted using the 'grdcontour' GMT module (e.g. gmt grdcontour rs_relief.nc $-\mathrm{R}-\mathrm{J}-\mathrm{C} 2000-\mathrm{W} 0.1 \mathrm{p}-\mathrm{O}-\mathrm{K}>>$ \$ps) and another spatial continuum, such as geoid or gravity isolines.

The specificity of the EGM-2008 grid is expressed in the separateness of their constituent tiles, which were therefore merged ("sewn") from the three tiles. Initially, the 3 tiles were converted from the binary format to the GRD format (e.g. by a code 'grdconvert s90e135/ EGM2008rs1.grd'). Afterwards, the spatial data range was checked by the GDAL library (gdalinfo EGM2008rs1.grd stats) for each respective tile. Then, the three tiles were visualized using the 'grdimage' module (example of the code: gmt grdimage EGM2008rs1.grd -Ccolors.cpt -R160/220/-81/-60 -JM5.5i -P $\mathrm{I}+\mathrm{a} 15+\mathrm{ne} 0.75-\mathrm{Xc}-\mathrm{K}>$ \$ps). The texts and annotations were added on the maps using the 'pstext' module (e.g. the code 'gmt pstext $-\mathrm{R}-\mathrm{J}-\mathrm{N}-\mathrm{O}-\mathrm{K}-\mathrm{F}+\mathrm{jTL}+\mathrm{f} 11 \mathrm{p}$,Helvetica,white+jLB $>>$ \$ps $<<$ EOF 185.5 -67.0 ROSS 186.5 -68.5 SEA EOF').

The conversion of the IMG raster format to the GRD format (necessary for plotting the marine free-air gravity initial grid on figure 5) was performed using the following code: 'img2grd grav_27.1.img -R160/250/-80/-40 -Ggrav.grd -T1 -I1 -E -S0.1 -V'. Different cartographic aspects (e.g. geologic generalization, visual representation or the topology of objects on the map) were reflected using a combination of various GMT modules (such as, for instance, 'psbasemap', 'grdcontour', 'makecpt', 'psscale', 'psconvert', 'img2grd').

As briefly demonstrated above, the syntax of the GMT scripting, to a certain extent, is similar to the principle used in the high-level programming languages, such as Python or R (e.g. applied in LEMENKOVA, 2020f, 2018). However, its applied language is more straightforward and clear. The GMT itself is written in the ANSI C programming language, is POSIX compliant and can be used as any other UNIX tool (WESSEL et al., 2013). The distinctiveness of the geological and geophysical phenomena was determined based on two criteria: 1) the values, highlighted by colours (e.g. depths for the bathymetry, level of anomalies for the gravity, height of thickness for the sediment cover); 2) their spatial extent highlighted by the isolines, which also includes the discreteness or continuity of the phenomena, reflected in the selected palette (e.g. based on the steepness of the relief in the continental slopes or the contiguous areas, or if there are relatively flat areas). The third stage of the research covered the data analysis by the correlation between the grids showing the distribution of sediment thickness over the seafloor area and the 
geophysical fields concerning the regional topography and character of the geological lineaments. Variation in sediment thickness was analysed both based on the literature in relevant publications included in the previous section (due to glacial, geomorphological and climate conditions) and determined by the analysis of the data distribution. The extent of the free-air gravity grids was analysed about the tectonic lineaments and objects formed in the course of the geologic evolution of the region and reflected in the modern topography of the seafloor.

\section{Sediment thickness of the Ross Sea region}

GlobSed 5 arc minute grid Version 3 by NOAA World Data Service for Geophysics Polar stereographic conformal projection. Central meridian $170^{\circ} \mathrm{W}$, standard parallel $60^{\circ} \mathrm{S}$

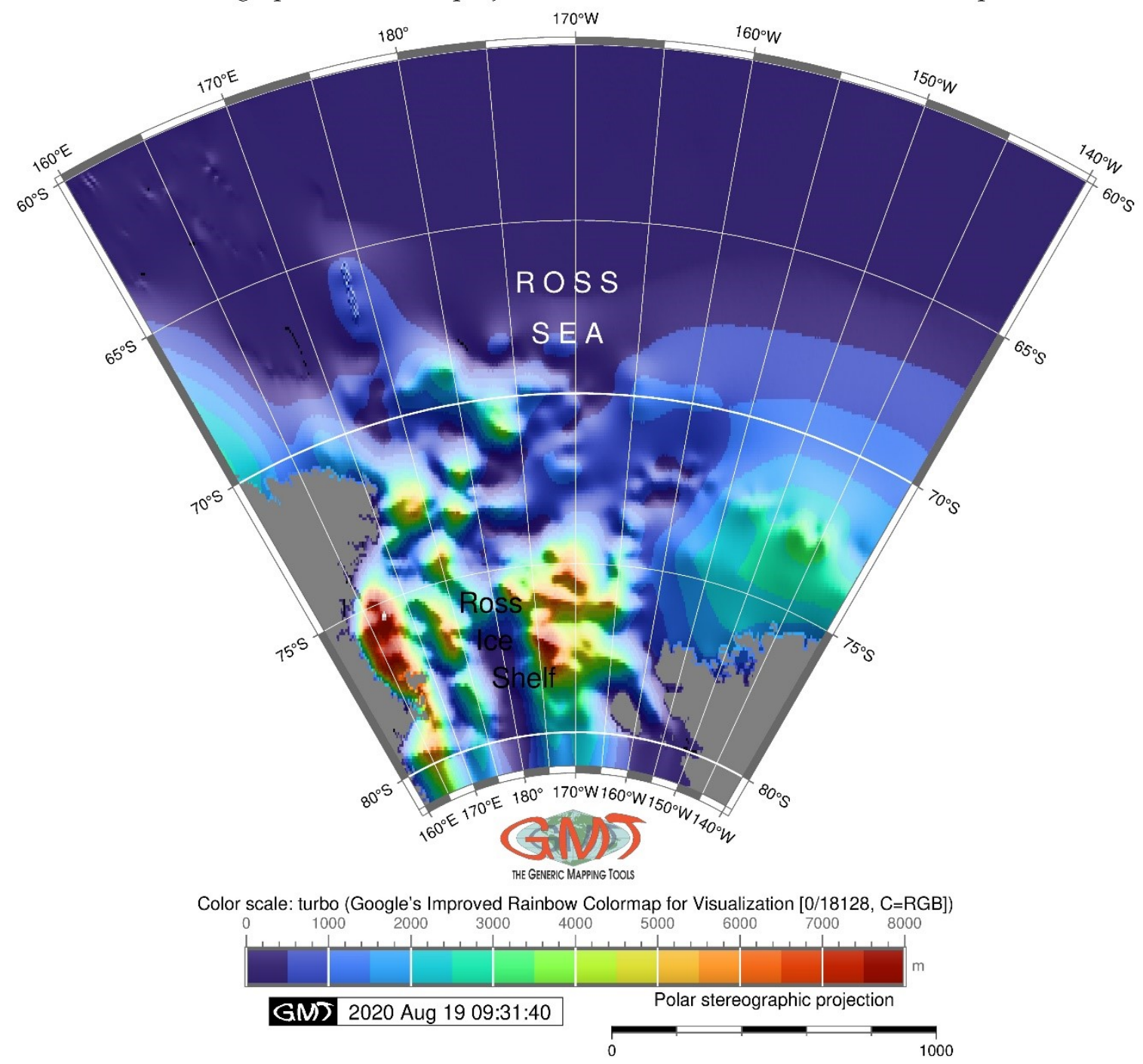

Figure 4 - Sediment thickness distribution in the basin of the Ross Sea. Source: author.

\section{RESULTS}


There are six resulting maps plotted on the GMT basis covering the area of the Ross Sea: Figure 1 showing the circumpolar map of the Antarctic region in 1:60,000,000 scale showing the location of the Ross Sea and the Weddell Sea (similar in the shelf extent, as mentioned earlier); Figure 2 showing the bathymetry extent of the Ross Sea; Figure 3 showing the tectonic settings and the geological lineaments over the study area; Figure 4 shows the distribution of the sediment thickness in the Ross Sea basin; Figure 5 and figure 6 showing the geophysical settings of the study area (marine free-air gravity approximations and geoid undulations model).

The topographic raster grids presented in this research, the ETOPO1 and GEBCO are highresolution digital elevation models that served as a foundation for mapping figure 1 and 2 . Using these models enables us to understand better the relief of the study area in such unreachable areas as the Antarctic, especially the topography of the areas covered by perennial ice. The figure 1 enables to comparatively analyse the bathymetry and the shelf distribution of the Ross Sea with regards to the other Antarctic seas. The analysis of GEBCO grid (Figure 2) shows that the bathymetry of the Ross Sea is generally shallow with around one-third of the sea to be shallower than $500 \mathrm{~m}$, about less than a half has the values between the 500 and $100 \mathrm{~m}$. The shelf break occurs at the level of the troughs at approximately $800 \mathrm{~m}$, according to the GEBCO grid (Figure 2).

The rest of the region located northward in the open areas is more in-depth than $1,000 \mathrm{~m}$, which is also supported by previous studies (DAVEY, 2004). Examples for the visualised tectonic data elements are fracture zones and tectonic plate boundaries, large igneous provinces (LIPs), submarine ridge (Figure 3). The depicted LIPs show a considerable accumulation of igneous rocks, sills, dikes, lava flows, arising when magma passes through the crust towards the surface and thus indicating on the past geological processes. As shown in figure 3, the Ross Sea is located between the two major tectonic plates, the Antarctic plate and the Pacific plate marked by a thick line border. Ridge formation accompanying the border between the two plates showing the unstable tectonic situation. The tectonic and geological maps help to reveal the origin of the modern topographic relief and trace its variation in the landforms.

The sediment of terrigenous material is widely distributed along the southern segment of the Ross Sea and can be studied on figure 4. The thickness of the sedimentary cover on the shelf of the Ross Sea varies depending on the topography of the basement surface (Figure 4). Generally, it represented the Mesozoic and Cenozoic deposits, and Paleozoic rocks in the depressions of the Precambrian basement. The pattern of sediment distribution generally mirrors the changes in the processes associated with the ice shelf movements that bring the sediments, as discussed in previous sections. Upon the analysis of figure 4, the highest values of the sediment thickness at above 7,500 $\mathrm{m}$ are dominating in the southwest segment of the Ross Sea closer to the Victoria Land. 
The second visible peak of the high values is distributed directly over the Ross Ice Shelf with values between 5,500 to $7,000 \mathrm{~m}$ in the quadrant with coordinates of $170^{\circ}-175^{\circ} \mathrm{W}$.

A smaller yet distinct peak with greater sediment thickness can be noted on the spot with coordinates $75^{\circ}-77^{\circ} \mathrm{S}, 176^{\circ}-178^{\circ} \mathrm{W}$ (Figure 4). An elongated several smaller dome-formed peaks with values between 4,000-5,000 $\mathrm{m}$ (Figure 4) stretches out like a series of the elongated geometric forms in a region of 70-75 S.

Marine free-air gravity anomaly: Ross Sea

Global gravity grid from CryoSat-2 and Jason-1, 1 min resolution

Lambert Azimuthal Equal-Area rectangular proj. Central meridian $170^{\circ} \mathrm{W}$, st. parallel $70^{\circ} \mathrm{S}$

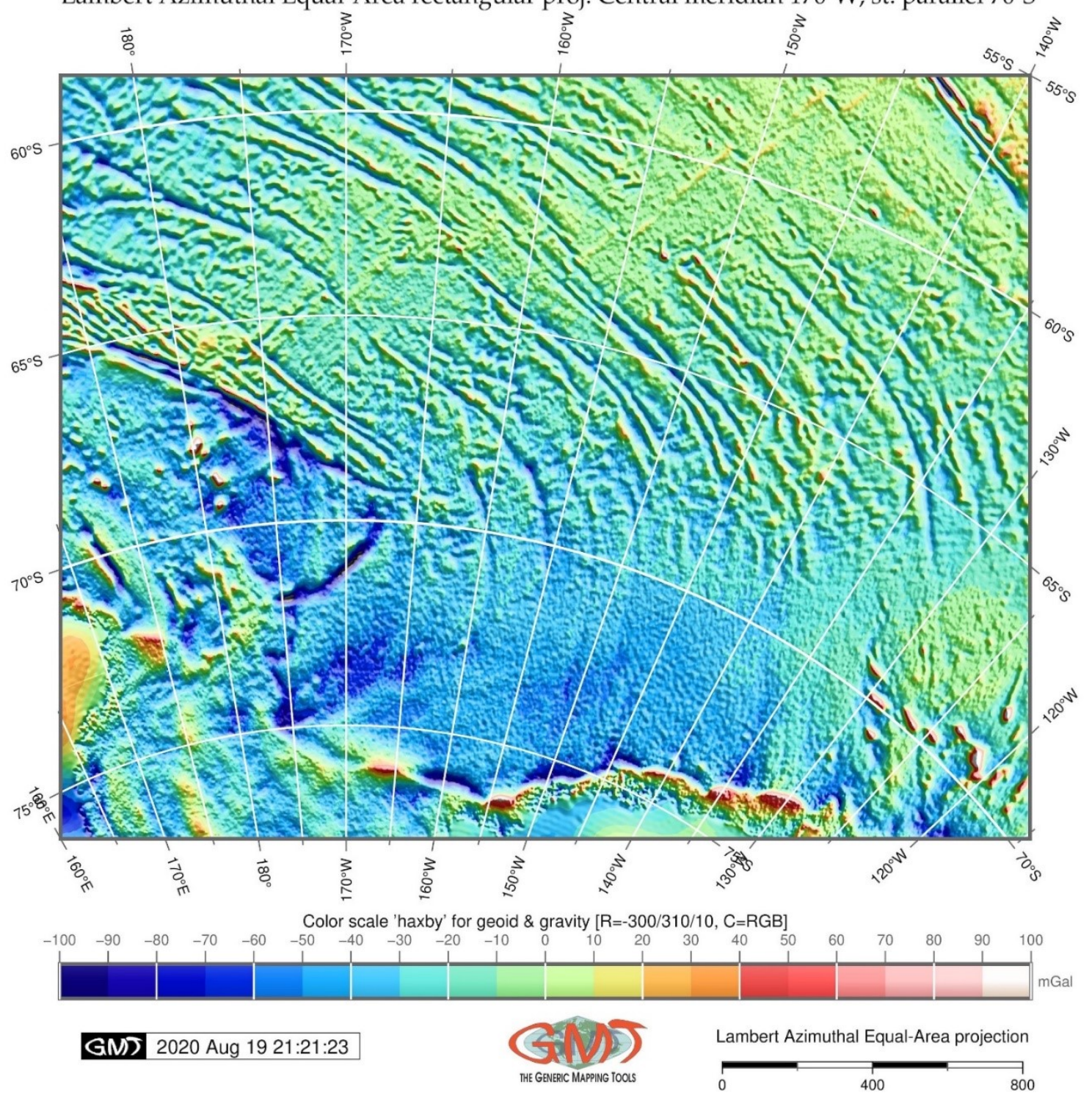

Figure 5 - Marine free-air gravity anomalies in the basin of the Ross Sea. Source: author.

This might indicate a local relief form of the bathymetry where the sediments are being accumulated after they are moved here from the external sources, for instance, the eolian processes: the Ross Sea is one of the most active cyclone active regions in the world (KING \& TURNER, 
1997) where the specific topography generates strong winds directed from land to the ocean, which, among other factors, contributes to the sediment accumulation.

Finally, the increased values of the sediment thickness between 2,500 to 3,000 $\mathrm{m}$ can also be seen in the region NE off the Sulzberger Bay (at the area of $70-75^{\circ} \mathrm{S}$ to $140-155^{\circ} \mathrm{W}$ ). Here, the contribution of the coastal area from the Marie Bird Land ice can explain the local increase in the sediment thickness. Using the multi-source data, as presented in this study, it is entirely possible to construct a series of the thematic maps using GMT, showing tectonic sculpting acting on the present topography of the seafloor reflected in the gravity anomalies (Figure 5).

The marine free-air gravity approximations spatially vary in the Ross Sea basin generally reflecting the geomorphic structures of the seafloor (Figure 5). Thus, the marked line depicting the border between the Antarctic and the Pacific tectonic plates can be distinguished as the slightly positive values ( 1 to $20 \mathrm{mGal}$ ). It also corresponds to the submarine ridges, which geometry can be seen on figure 3. The fracture zones, generally stretching in an NW-SE direction, can be seen as a series of the negative anomalies with values between the -60 to $-50 \mathrm{mGal}$.

A remarkable correlation between the gravity and the topography of the sea-land border in the Marie Bird Land area is well reflected in the coastal line and a set of the higher values in the free-air gravity: 40-50 mGal and higher along the coastal border of the Marie Bird Land (Figure 5). The values between the -60 to $-80 \mathrm{mGal}$ are notable along with the submarine toughs and minor local trenches stretching parallel in the western part of the basin: e.g. the trough stretching in NW$\mathrm{SE}$ direction in the $170^{\circ} \mathrm{W}-175^{\circ} \mathrm{E}, 65^{\circ} \mathrm{S}-68^{\circ} \mathrm{S}$ (Figure 5) and another one, stretching in an almost perpendicular direction to it, in an area between the $167^{\circ} \mathrm{W}-175^{\circ} \mathrm{W}, 70^{\circ} \mathrm{S}-72^{\circ} \mathrm{S}$. Such correlations are clearly visible on the map and can assist in detecting geological lineaments and bathymetric depressions. Furthermore, the geometric axis of the negative gravity anomalies, in general, coincides with the axis of the submarine topographic depressions and troughs. Repeating the shape form of the bathymetric relief of the Ross Sea, the negative gravity anomalies are noted over the SE coasts of the sea close to the Marie Bird Land, which stresses the structural geologic relationship between the geophysical and tectonic settings.

The derived data of the EGM-2008 geoid is shown in figure 6, which represented the abstract phenomenon of the geopotential model of the Ross Sea region. The geoid (Figure 6) has been mapped using the EGM-2008 grid (PAVLIS et al., 2012), which in turn presents an updated and detailed revision of the EGM96 grid (LEMOINE et al., 1998). To determine the variations of the geoid values, it is usually sufficient to analyse the content of the maps which are plotted based on the EGM-2008 grid. Hence, the mapping of the detailed geoid (Figure 6) gravitational model shows the following results. It revealed a generally domed data distribution in the geoid heights with the lowest values of $-66 \mathrm{~m}$ in the centre of the sea (Figure 6). 


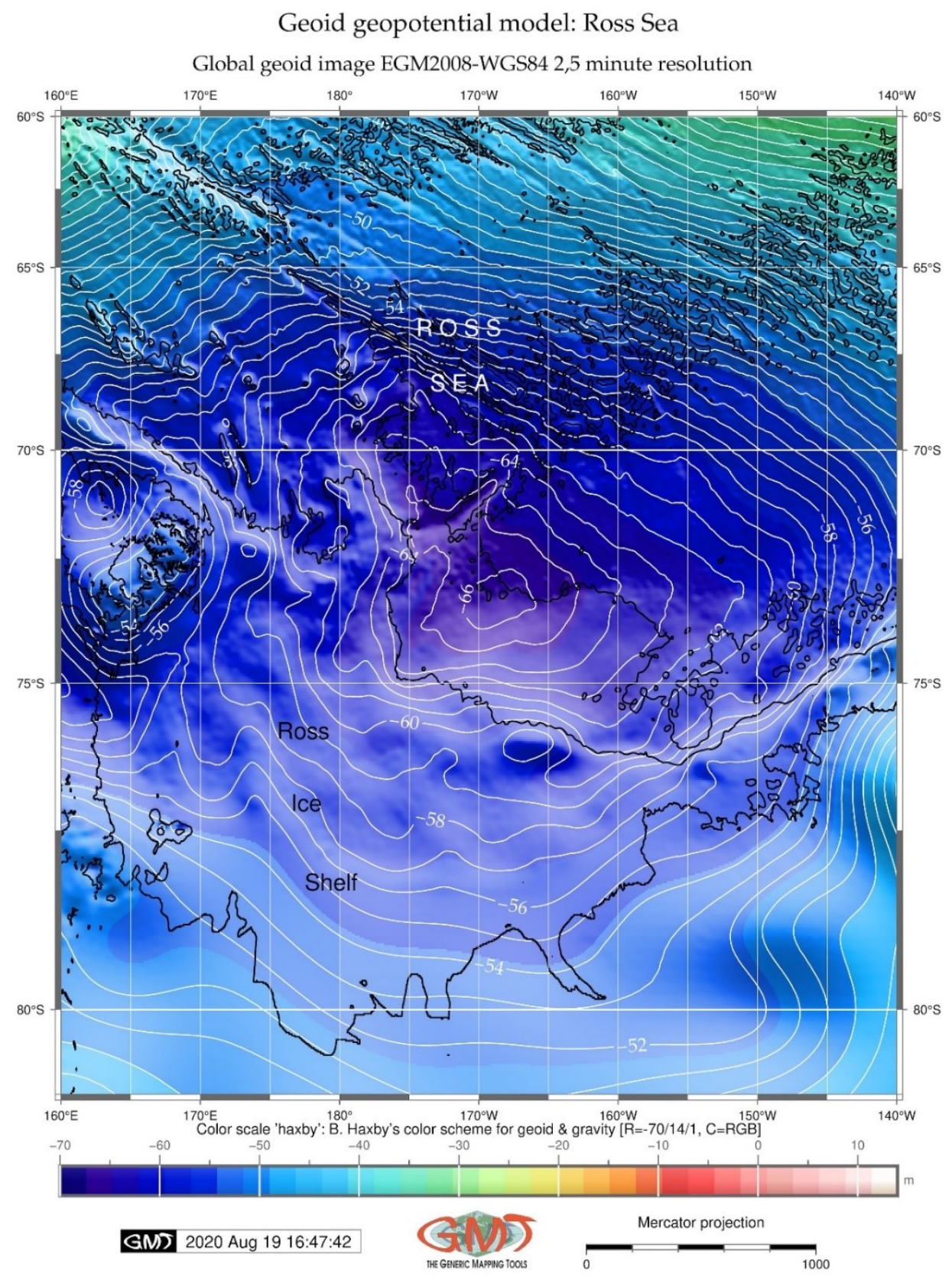

Figure 6 - Geoid geopotential model undulations over the basin of the Ross Sea. Source: author.

The Ross Ice Shelf shows gradually decreasing values from -51 to $-63 \mathrm{~m}$ when moving northwards. Other notable areas show the area of the Oates Land with a visible area encircling values from -56 to $-52 \mathrm{~m}$, that is the higher values fo the geoid correspond to the topographic increase in elevation in this part of the region. In general, the coastal land areas and terrestrial regions demonstrated higher values of the geoid comparing to the center of the sea basin (e.g. also, comparing the Marie Bird Land with -49 to $-48 \mathrm{~m}$ comparing to the central area with the minimal value at $-66,517 \mathrm{~m}$ according to EGM-2008 grid).

\section{DISCUSSION}


The above analysis has demonstrated a practicable and replicable data-driven GMT-based approach to visualise the correlations between the topography, tectonic setting, sediment distribution, geophysical settings and gravitational geoid model in the Ross Sea, specifically showing spatial interaction patterns between the geological and topographic settings. The use of the high-resolution raster datasets as a basis for digital cartographic visualisation provides the potential for a complex geographical analysis in an unreachable region of the Earth, such as the Antarctic and the Southern Ocean.

The applied variety of the GMT modules enabled to perform a print-quality mapping for a multidisciplinary spatial analysis combining multi-source vector and raster data. It has further been demonstrated that an open-source GMT is an economical means to process geospatial data and that a GMT-based cartographic output is feasible without the need of the expensive commercial ArcGIS used by several previous studies (e.g. ANDRIAMAMONJISOA \& HUBERT-FERRARI, 2019a, 2019b; LEMENKOVA et al., 2012; WILLIAMS et al., 2018).

Accumulation of sediments from the various origin, such as rock debris, mineral grains, clay minerals, resulting in terrigenous sedimentation is caused by the transfer of the materials from the coastal land (LEMENKOVA, 2020e). This typically includes transportation, deposition and dislocation of both terrigenous and biogenous sediments. Comparing to the biogenous, the terrigenous type of sedimentation prevails, usually, 7 to 10 times (LISITZIN \& RODOLFO, 1972). The observed sediment thickness in the Ross Sea clearly shows the dominating higher values in its southern part, which is affected by the closeness of the ice shelf bringing the terrigenous sediment from the coastal land. The reasons for the marine sedimentation are diverse. Apart from the glaciers melting and deposits transferred to the seafloor, a particular contribution is made by dust moved by the wind activity and storms (LEMENKOVA, 2019e). The glacial marine sediments transferred by coastal glaciers are deposited in the proximity of the shelf areas. They, therefore, do not reach open water areas in the northern basin of the Ross Sea.

The presented graphical mapping analysis of the correlations between the geological and geophysical phenomena in the Ross Sea succinctly summarise the complexity of these processes, but also offer a basis for further studies of the Antarctic marginal sea basins. The scripting-based machine learning approach by GMT has yielded high-resolution data that were used as new information (BERRY, 1988). The results were interpreted regarding the interaction patterns among bathymetry of the seafloor and distribution of the sediment thickness, geological and tectonic settings and geophysical interpolated grids. It has shown, for instance, that the distribution of the sediment cover over the seafloor is affected by the closeness of the ice-covered coastal area from the Oates Land, the Victoria Land and the Marie Bird Land, where the ice shelves make a significant contribution to the sedimentation process. On the other hand, this is also affected by the 
flat relief of the shelf area where the sediments are being accumulated over time. There is some evidence of the correlation between the marine free-air anomalies (Figure 5) and linear oceanic features, such as fracture zones (Figure 3) which enables to conclude that geophysical settings are reflected on the geological phenomena and can be visualised on the thematic maps.

\section{CONCLUSION}

Cartography always aims at a better representation of the phenomena of the Earth, geologic objects, topography and their interrelations. That is, the objective of the cartographic visualisation is to envisage the elements on maps as close to the real world and as precise as possible (SMITH, 1993; BREWER, 2005; FISHER, 1982; LEMENKOVA, 2020c, 2020d; SCHENKE \& LEMENKOVA, 2008; HUBER \& SCHNEIDER, 1999). This is the requirement which the GMT successfully met using standards of scripting methodology supported by the high-resolution datasets. Among other progressive methods are statistical data analysis and processing (e.g. DAVIS, 1973; LEMENKOVA, 2019e, 2019f; EBDON, 1977).

Processing of the geospatial grids by GIS applications is a part of the geospatial analysis (e.g. SUETOVA et al., 2005a, 2005b; LEMENKOVA, 2011; KLAUCO et al., 2013, 2017). Various GIS approaches for environmental and geological modelling are performed nowadays. These may include mapping, geological profiling, statistical plotting and analysis, modelling, numerical computations and graphical visualisation (DECESARI et al., 2007; LEMENKOVA, 2020b, 2019c, LINDH, 2004; LINDH et al., 2000; KLAUCO et al., 2014). Depending on data availability, the multi-source data analysis in geological studies and earthworks is driven by data acquisition from various sources (EVERITT, 1978; LEMENKOVA, 2020a)

This paper presented the use of high-resolution grids such as GEBCO, ETOPO1, EGM2008, GlobSed, processed by computational simulations of raster grids using GMT scripting techniques. Various modules of GMT have been used for plotting specific cartographic elements, such as isolines, legend, annotations, adding grid ticks, approximating raster image, selecting and adjusting colour palettes, etc. Speed and repeatability of the GMT scripting enable its batch processing of raster grids and vector layers, which is, beyond doubts, one of its most important advantages. Therefore, the GMT-based seafloor mapping system, as demonstrated in this research, can produce a detailed picture of the seafloor immediately after the data input using the machine learning algorithms of the processing of the big datasets.

\section{REFERENCES}


AINLEY, D. G. A history of the exploitation of the Ross Sea, Antarctica. Polar Record, v. 46, n. 238, p. 233-243, 2010.

AINLEY, D. G. Biomass of Birds and Mammals in the Ross Sea. In: SIEGFRIED, W. R.; CONDY, P. R.; LAWS, R. M. (Eds). Antarctic Nutrient Cycles and Food Webs. Berlin: Berlin, 1985. $702 p$.

AMANTE C.; EAKINS B. W. Etopo1 1 arc-minute global relief model: Procedures, data sources and analysis. NOAA technical memorandum, 2009. 25p.

ANDRIAMAMONJISOA, S. N.; HUBERT-FERRARI, A. Augmenting comprehension of geological relationships by integrating 3D laser scanned hand samples within a GIS environment. Computers \& Geosciences, v. 103, p. 152-163, 2019a.

ANDRIAMAMONJISOA, S. N.; HUBERT-FERRARI, A. Combining geology, geomorphology and geotechnical data for a safer urban extension: Application to the Antananarivo capital city (Madagascar). Journal of African Earth Sciences, v. 151, p. 417-437, $2019 \mathrm{~b}$.

ARRIGO, K. R.; VAN DIJKEN, G. L.; AINLEY, D. G.; FAHNESTOCK, M. A.; MARKUS, T. Ecological impact of a large Antarctic iceberg. Geophysical Research Letters, v. 29, n. 7, p. 8184, 2002.

BERRY, J. K. Maps as Data: Fundamental Considerations in Computer-Assisted Map Analysis. International Journal of Geographical Information Systems, v. 1, p. 273-284, 1988.

BIRD, P. An updated digital model of plate boundaries. Geochemistry, Geophysics, Geosystems, v. 4, n. 3, p. 1027, 2003.

BRANCOLINI, G.; COOPER, A. K.; COREN, F. Seismic Facies and Glacial History in the Western Ross Sea (Antarctica). In: COOPER, A. K.; BARKER, P. F.; BRANCOLINI, G. (Eds.) Geology and seismic stratigraphy of the Antarctic margin, Antarctic Research Series. AGU, Washington: AGU, 1995. p. 209-234.

BREWER, C. A. Designing Better Maps. A Guide for GIS Users. Redlands: ESRI Press, 2005. 250 p.

CANDE, S. C.; STOCK, J. M. Constraints on the timing of extension in the Northern Basin, Ross Sea. In: FUTTERER, D. K.; DAMASKE, D.; KLEINSCHMIT, G.; MILLER, H.; TESSENSOHN, F. (Eds.) Antarctica, Contributions to Global Earth Science. Wurzburg, 2006. 477p.

COOPER, A. K.; DAVEY, F. J.; BEHRENDT, J. C. Seismic stratigraphy and structure of the Victoria Land Basin, western Ross Sea, Antarctica. In: COOPER, A. K.; DAVEY, F. J. (Eds.). The Antarctic Continental Margin: Geology and Geophysics of the Western Ross Sea. Circum-Pacific Council for Energy and Mineral Resources. Houston, 1987. 253p.

DAVEY, F. J.; CANDE, S. C.; STOCK, J. M. Extension in the western Ross Sea region-links between Adare Basin and Victoria Land Basin. Geophysical Research Letters, v. 33, n. 20, 2006.

DAVEY, F. J. Ross Sea bathymetry, 1:2000000, version 1.0. Institute of Geological \& Nuclear Sciences geophysical map 16. Institute of Geological \& Nuclear Science Ltd., New Zealand: Lower Hutt, 2004. 
DAVEY, F. J.; CANDE, S. C.; STOCK, J. M. Extension in the western Ross Sea region-links between Adare Basin and Victoria Land Basin. Geophysical Research Letters, v. 33, n. 20, p. 1-5, 2006.

DAVIS, J. C. Statistics and Data Analysis in Geology. J. Wiley \& Sons, 1973. 550p.

DECESARI, R. C.; SORLIEN, C. C.; LUYENDYK, B. P.; WILSON, D. S.; BARTEK, L.; DIEBOLD, J.; HOPKINS, S. E. Regional seismic stratigraphic correlations of the Ross Sea: Implications for the tectonic history of the West Antarctic Rift System. US Geological Survey and The National Academies, 2007. p. 1-4.

DECESARI, R. C. The Mesozoic and Cenozoic Depositional, Structural, and Tectonic Evolution of the Ross Sea, Antarctica. Santa Barbara: University of California, 2006. 232p.

EASTMAN, J. T. The nature of the diversity of Antarctic fishes. Polar Biology, v. 28, p. 93-107, 2005.

EASTMAN, J. T.; BARRY, J. P. Underwater video observation of the Antarctic toothfish Dissostichus mawsoni (Perciformes: Nototheniidae) in the Ross Sea, Antarctica. Polar Biology, v. 25, p. 391-395, 2002.

EBDON, D. Statistics in Geography. A Practical Approach. Oxford: Blackwell, 1977. 195p.

EVERITT, B. S. Graphical Techniques for Multivariate Data. Heinemann Educational Books, 1978. 117p.

FISHER, H. T. Mapping information: The graphic display of quantitative information. Cambridge: Abt Books, 1982. 384p.

GAUGER, S.; KUHN, G.; GOHL, K.; FEIGL, T.; LEMENKOVA, P.; HILlENBRAND, C. Swath-bathymetric mapping. Reports on Polar and Marine Research, v. 557, p. 38-45, 2007.

GEBCO COMPILATION GROUP. GEBCO $\mathbf{2 0 2 0}$ Grid. Avaiable at: https://www.bodc.ac.uk/data/published_data_library/catalogue/10.5285/a29c5465-b138-234d-e0536c86abc040b9/. Access on: 8 ago. 2020.

GDAL/OGR CONTRIBUTORS. GDAL/OGR Geospatial Data Abstraction software Library. Open Source Geospatial Foundation. Avaiable at: https://gdal.org. Access on: 08 ago. 2020.

GOODCHILD, M. Geographical information science. International journal of geographical information systems, v. 6, n. 1, p. 31-45, 1992.

HUBER, M.; SCHNEIDER, D. Spatial data standards in view of models of space and the functions operating on them. Computers \& Geosciences, v. 25, n. 1, p. 25-38, 1999.

JACOBS, S.; COMISO, J. Sea ice and oceanic processes on the Ross Sea continental shelf. Journal of Geophysical Research, v. 94, n. 12, p. 18195-18211, 1989.

JACOBS, S. S.; GIULIVI, C. G.; MELE, P. A. Freshening of the Ross Sea during the Late 20th century. Science, v. 297, p. 386-389, 2002. 
KING, J. C.; TURNER, J. Antarctic Meteorology and Climatology. New York: Cambridge University Press, 1997. 409p.

KLAUČO, M.; GREGOROVÁ, B.; STANKOV, U.; MARKOVIĆ, V.; LEMENKOVA, P. Determination of ecological significance based on geostatistical assessment: a case study from the Slovak Natura 2000 protected area. Central European Journal of Geosciences, v. 5, n. 1, p. 2842, 2013.

KLAUČO, M.; GREGOROVÁ, B.; STANKOV, U.; MARKOVIĆ, V.; LEMENKOVA, P. Landscape metrics as indicator for ecological significance: assessment of Sitno Natura 2000 sites, Slovakia. Ecology and Environmental Protection. Proceedings of the International Conference, p. 19-20, 2014.

KLAUČO, M.; GREGOROVÁ, B.; STANKOV, U.; MARKOVIĆ, V.; LEMENKOVA, P. Land planning as a support for sustainable development based on tourism: A case study of Slovak Rural Region. Environmental Engineering and Management Journal, v. 2, n. 16, p. 449-458, 2017.

KUHN, G.; HASS, C.; KOBER, M.; PETITAT, M.; FEIGL, T.; HILLENBRAND, C. D.; KRUGER, S.; FORWICK, M.; GAUGER, S.; LEMENKOVA, P. The response of quaternary climatic cycles in the South-East Pacific: development of the opal belt and dynamics behavior of the West Antarctic ice sheet. In: Expeditions programm, 2006. 49p.

LAWVER, L. A.; GAHAGAN, L. M. Constraints on timing of extension in the Ross Sea region. Terra Antartica, v. 1, p. 545-552, 1994.

LECHTHALER M. The World Image in Maps - From the Old Ages to Mercator. In: Cartography and Art. Lecture Notes in Geoinformation and Cartography. Berlin: Springer, 2009. 391p.

LEMENKOVA, P. Visualization of the geophysical settings in the Philippine Sea margins by means of GMT and ISC data. Central European Journal of Geography and Sustainable Development, v. 2, n. 1, p. 5-15, 2020a.

LEMENKOVA, P. GMT-based geological mapping and assessment of the bathymetric variations of the Kuril-Kamchatka Trench, Pacific Ocean. Natural and Engineering Sciences, v. 5, n. 1, p. 1$17,2020 \mathrm{~b}$.

LEMENKOVA, P. GMT Based Comparative Geomorphological Analysis of the Vityaz and Vanuatu Trenches, Fiji Basin. Geodetski List, v. 74, n. 1, p. 19-39, 2020c.

LEMENKOVA, P. Variations in the bathymetry and bottom morphology of the Izu-Bonin Trench modelled by GMT. Bulletin of Geography. Physical Geography Series, v. 18, n. 1, p. 41-60, 2020d.

LEMENKOVA, P. Integration of geospatial data for mapping variation of sediment thickness in the North Sea. Scientific Annals of the Danube Delta Institute, v. 25, p. 129-138, 2020e.

LEMENKOVA, P. R Libraries \{dendextend\} and \{magrittr\} and Clustering Package scipy.cluster of Python For Modelling Diagrams of Dendrogram Trees. Carpathian Journal of Electronic and Computer Engineering, v. 13, n. 1, p. 5-12, 2020 f.

LEMENKOVA, P. Topographic surface modelling using raster grid datasets by GMT: example of the Kuril-Kamchatka Trench, Pacific Ocean. Reports on Geodesy and Geoinformatics, v. 108, p. 9-22, 2019a. 
LEMENKOVA, P. GMT Based Comparative Analysis and Geomorphological Mapping of the Kermadec and Tonga Trenches, Southwest Pacific Ocean. Geographia Technica, v. 14, n. 2, p. 3948, 2019b.

LEMENKOVA, P. Geomorphological modelling and mapping of the Peru-Chile Trench by GMT. Polish Cartographical Review, v. 51, n. 4, p. 181-194, 2019c.

LEMENKOVA, P. AWK and GNU Octave Programming Languages Integrated with Generic Mapping Tools for Geomorphological Analysis. GeoScience Engineering, v. 65, n. 4, p. 1-22, 2019d.

LEMENKOVA, P. Statistical Analysis of the Mariana Trench Geomorphology Using R Programming Language. Geodesy and Cartography, v. 45, n. 2, p. 57-84, 2019e.

LEMENKOVA, P. Testing Linear Regressions by StatsModel Library of Python for Oceanological Data Interpretation. Aquatic Sciences and Engineering, v. 34, p. 51-60, $2019 \mathrm{f}$.

LEMENKOVA, P. R scripting libraries for comparative analysis of the correlation methods to identify factors affecting Mariana Trench formation. Journal of Marine Technology and Environment, v. 2, p. 35-42, 2018.

LEMENKOVA, P.; PROMPER, C.; GLADE, T. Economic Assessment of Landslide Risk for the Waidhofen a.d. Ybbs Region, Alpine Foreland, Lower Austria. In: INTERNATIONAL SYMPOSIUM ONMLANDSLIDES, 11., 2012, Banff. Proceedings... Banf, 2012. p. 279-285.

LEMENKOVA, P. Seagrass Mapping and Monitoring Along the Coasts of Crete, Greece. M.Sc. Thesis. Netherlands: University of Twente, 2011. 158p.

LEMOINE, F. G.; KENYON, S. C.; FACTOR, J. K.; TRIMMER, R. G.; PAVLIS, N. K.; CHINN, D. S.; COX, C. M.; KLOSKO, S. M.; LUTHCKE, S. B.; TORRENCE, M. H.; WANG, Y. M.; WILliAMSON, R. G.; PAVLIS, E. C.; RAPP R. H.; OLSON, T. R. The Development of the Joint NASA GSFC and the National Imagery and Mapping Agency (NIMA) Geopotential Model EGM96. NASA, 1998. 584p.

LINDH, P. Compaction- and strength properties of stabilised and unstabilised fine-grained tills. Lund: Lund University, 2004. 373p.

LINDH, P.; DAHLIN, T.; SVENSSON, M. Comparisons Between Different Test Methods for Soil Stabilisation. In: ISRM INTERNATIONAL SYMPOSIUM. 2000. Proceedings... Melbourne: Lund University, 2000. p. 1-7.

LISITZIN, A. P.; RODOLFO, K. S. Sedimentation in the World Ocean: With Emphasis On the Nature, Distribution and Behavior of Marine Suspensions. 1972. 197p.

LITVIN, V. M. Morphostructure of the ocean floor. Moscow: Nedra, 1987. 311p.

PAVLIS, N. K.; HOLMES, S. A.; KENYON, S. C.; FACTOR, J. K. The development and evaluation of the Earth Gravitational Model 2008 (EGM2008). Journal of Geophysical Research, v. 117, p. 04406, 2012. 
PARISH, T. R.; CASSANO, J. J.; SEEFELDT, M. W. Characteristics of the Ross Ice Shelf air stream as depicted in Antarctic Mesoscale Prediction System Simulations. Journal of Geophysical Research, v. 111, p. 12109, 2006.

SAINO N.; GUGLIELMO L. ROSSMIZE Expedition: Distribution and Biomass of Birds and Mammals in the Western Ross Sea. In: FARANDA, F. M.; GUGLIELMO, L.; IANORA, A. (Eds). Ross Sea Ecology. Berlin: Springer, 2000. 604p.

SANDWELL, D. T., MÜLLER, R. D.; SMITH, W. H. F.; GARCIA, E.; FRANCIS, R. New global marine gravity model from CryoSat-2 and Jason-1 reveals buried tectonic structure. Science, v. 346, n. 6205, p. 65-67, 2014.

SCHENKE, H. W.; LEMENKOVA, P. Zur Frage der Meeresboden-Kartographie: Die Nutzung von AutoTrace Digitizer für die Vektorisierung der Bathymetrischen Daten in der Petschora-See. Hydrographische Nachrichten, v. 81, p. 16-21, 2008.

SMITH, W. H. F. On the accuracy of digital bathymetric data. Journal of Geophysical Research, v. 98, n. 6, p. 9591-9603, 1993.

STRAUME, E. O.; GAINA, C.; MEDVEDEV, S.; HOCHMUTH, K.; GOHL, K.; WHITTAKER, J. M.; ABDUL FATTAH, R.; DOORNENBAL, J. C.; HOPPER, J. R. GlobSed: Updated total sediment thickness in the world's oceans. Geochemistry, Geophysics, Geosystems, v. 20, n. 4, p. 1756-1772, 2019.

SUETOVA, I. A.; USHAKOVA, L. A.; LEMENKOVA, P. Geoinformation mapping of the Barents and Pechora Seas. Geography and Natural Resources, v. 4, p. 138-142, 2005a.

SUETOVA, I. A.; USHAKOVA, L. A.; LEMENKOVA, P. Geoecological Mapping of the Barents Sea Using GIS. In: INTERNATIONAL CARTOGRAPHIC CONFERENCE. 2005, La Coruna. Proceedings... La Coruna, 2005b.

WESSEL, P.; SMITH, W. H. F. Free software helps map and display data. Eos Transactions of the American Geophysical Union, v. 72, n. 41, p. 441, 1991.

WESSEL, P.; SMITH, W. H. F. New version of the Generic Mapping Tools released. Eos Transactions of the American Geophysical Union, v. 76, n. 33, p. 329, 1995.

WESSEL, P.; SMITH, W. H. F. A Global Self-consistent, Hierarchical, High-resolution Shoreline Database. Journal of Geophysical Research, v. 101, p. 8741-8743, 1996.

WESSEL, P.; SMITH, W. H. F.; SCHARROO, R.; LUIS, J. F.; WOBBE, F. Generic mapping tools: Improved version released. Eos Transactions American Geophysical Union, v. 94, n. 45, p. 409-410, 2013.

WILliAMS, D. A.; BUCZKOWSKI, D. L.; MEST, S. C.; SCUlLY, J. E. C.; PLATZ, T.; KNEISSL, T. Introduction: The geologic mapping of Ceres. Icarus, v. 316, p. 1-13, 2018. 